\title{
How Anglo/Dutch Collaboration Produced Radical Long-Term Integrated Coastal Planning Solutions for a Vulnerable Peninsula on Britain's South Coast
}

\author{
Jane Cunningham* and Carolyn Cobbold
}

MPP Project Officer at Manhood Peninsula Partnership, Portsmouth, England, United Kingdom

\begin{abstract}
Manhood peninsula partnership

This paper describes how a small and vulnerable coastal community achieved one of the first examples in Britain of an integrated long-term planning strategy by reaching out to their European neighbours. Centred around Medmerry, Europe's largest open-coast realignment scheme when it opened in November 2013, the strategy incorporates integrated and long-term adaptation of the Manhood Peninsula's economy, environment and planning, recognising the particular climate change, development and infrastructure challenges facing a low lying, exposed peninsula in the south east of England. This paper describes the unusual history behind Towards ICZM on the Manhood Peninsula, demonstrating the value of listening to locals, combining different approaches and drawing on diverse disciplines and international experience and expertise. The paper describes how two local residents facilitated a ground-breaking five-day planning workshop involving experts from the Netherlands and Britain brainstorming with the local community and local authorities to explore a variety of sustainable, resilient and radical coastal management strategies to ensure the long term economic, social and environment future for the whole peninsula. The Going Dutch workshop helped a diverse and divided local population to understand and articulate their problems and aspirations. It also allowed representatives from local and national organisations to exchange views and concerns with each other and with local people in an informal but constructive manner. As a result of the workshop, the Manhood Peninsula Partnership was created, enabling further exploration and implementation of sustainable coastal, environmental and economic adaptations for the area. The paper outlines the partnership and its achievements, including its ICZM strategy that has been incorporated this year into the Chichester District Local Plan.
\end{abstract}

Keywords: ICZM; Climate change; Community engagement; Interdisciplinary working; International exchange; Coastal intervention;

Integrated coastal zone management; Coastal partnerships

\section{Introduction}

This paper details the events that followed a chance conversation between two local residents of a low-lying coastal peninsula in 1997 that led to closer cooperation between residents, businesses and authorities in the area and, ultimately, a radical coastal intervention that has been incorporated into one of the first Integrated coastal zone management strategies implemented in the UK [1].

The two residents, a Dutch spatial planner and a British risk management journalist, shared concerns about the lack of integrated and long-term planning for an area clearly suffering water management and infrastructure problems likely to worsen with climate change. Coming themselves from different geographical and cultural backgrounds and working in diverse professional paradigms, they recognised the importance of bringing together all stakeholders in the area as well as drawing on expertise and experience from a variety of diverse professional disciplines and cultural and geographical backgrounds. Working voluntarily, the residents raised funding from local and national organisations (British and Dutch), to host a fiveday workshop with 28 Dutch and British experts on coastal and water management issues and integrated planning [2]. Briefed with extensive background material provided by the area's local communities and local and national authorities, the task of the workshop participants, all working without payment, was to formulate ideas about a sustainable integrated planning approach for the future of the Manhood Peninsula.

The workshop included a comparison of Dutch and British national, regional and local planning and coastal and inland flood defence arrangements; extensive exchange of knowledge between methodologies and approaches used in different disciplines; and continual input from the local community. By dividing the participants into mixed disciplinary working groups, the workshop produced three separate long-term scenarios for the Manhood peninsula, incorporating new ideas to solve existing problems in an integrated sustainable manner.

Many of these ideas, including a radical coastal realignment, are now being implemented in the area as part of an integrated coastal management strategy now incorporated into the district's long-term development plan.

\section{Background}

Integrated Coastal Zone Management seeks to balance environmental, economic and social objectives to enable the sustainable management of the coastal zone. It is a process, which seeks to integrate

*Corresponding author: Dr. Jane Cunningham, MPP Project Officer at Manhood Peninsula Partnership, Portsmouth, England, United Kingdom, Tel: 01243-521091; E-mail: JCunningham@chichester.gov.uk

Received July 09, 2015; Accepted July 20, 2015; Published July 31, 2015

Citation: Cunningham J, Cobbold C (2015) How Anglo/Dutch Collaboration Produced Radical Long-Term Integrated Coastal Planning Solutions for a Vulnerable Peninsula on Britain's South Coast. J Coast Zone Manag 18: S1-001. doi: 10.4172/2473-3350.1000S1-001

Copyright: @ 2015 Cunningham J, et al. This is an open-access article distributed under the terms of the Creative Commons Attribution License, which permits unrestricted use, distribution, and reproduction in any medium, provided the original author and source are credited. 
the different policies that have an effect on the coast whilst bringing together various stakeholders to inform, support, and implement these policies. There is a strong focus upon partnership working and informed collaboration between stakeholders.

In 1997 the link between strategic government policies and local government implementation was not clear as shown in the Introduction. Since the Going Dutch workshops coastal areas have been closely scrutinized at national and local government levels. This has led to new legislation affecting the environmental, community and economic perceptions of the coast.

A Strategy for 'Promoting an Integrated Approach to the Management of Coastal Areas in England' was produced by Defra (Department of Environment, Food \& Rural Affairs) in 2009 [3]. The document sets out the UK Government's visions for coastal management, objectives and future actions to achieve the vision, and briefly explains how all the changes currently being taken forward will work together in coastal areas.

The planning principles to implement the approach are set out in the UK National Planning Policy Framework (DCLG 2012) [4], which states that:

'In coastal areas, local planning authorities should take account of marine plans and apply Integrated Coastal Zone Management across local authority and land/sea boundaries'.

The local policy context for integrated coastal zone management is the Sustainable Community Strategy developed by the Local Strategic Partnership for Chichester District, entitled 'Chichester District: A Very Special Place'. The strategy sets out a shared vision for Chichester District from 2009 to 2016 [5].

The Local Plan for Chichester District (Chichester District Council 2015) takes this a stage further by detailing planning policies designed to support issues of importance to local communities including coastal zone management [6].

In addition to the examples cited in Table 1 the UK Marine Management Organisation (MMO) was established in 2010 and is responsible for preparing Marine Plans for England, which include a strong ICZM component [7].

\section{Examples of other coastal and ICZM initiatives in the UK}

Following the EU demonstration programme on integrated coastal zone planning in the late 1990s there have been several coastal planning initiatives along the UK.

However, as a result of no national coastal policy and a lack of a coordinating structure or mechanism for ICZM there has been no standard methodology or approach developed. ICZM initiatives are instigated by various people and organisations and implemented by locally formed coastal partnerships [8].

Over 50 flourishing partnerships exist round the UK coast and include Solent Forum - Southampton, Hampshire; North West Coastal Forum-Southport, Mersyside; Devon Maritime - Exeter, Devon; Durham Heritage Coast Partnership - Durham, Co Durham. Although the purpose of the groups varies according to local need, links between the partnerships are strong, and are maintained by a national coordinating body, the Coastal Partnerships Network [9].

The coastal partnerships are a vital mechanism for integrating the needs and management of many different initiatives, which include:

\begin{tabular}{|c|c|}
\hline 1995-1998 & EU demonstration programme on ICZM \\
\hline 2002 & EU Recommendation on implementing ICZM \\
\hline 2004 & UK ICZM Stocktake \\
\hline 2006 & UK consultation seeking views on promoting ICZM \\
\hline 2009 & UK strategy for promoting ICZM \\
\hline 2009 & Coastal Change Pathfinder Project \\
\hline 2010 & Consultation on implementing ICZM legislation in UK \\
\hline 2011 & $\begin{array}{l}\text { UK Marine Policy Statement - recommending the embedding } \\
\text { of key principles of ICZM in all planning and decision making } \\
\text { functions in coastal and marine areas. }\end{array}$ \\
\hline 2012 & National Planning Policy Framework includes ICZM \\
\hline 2013 & EU agreement on Maritime Spatial Planning Directive \\
\hline 2014 & Marine Management Organisation - Marine Plans \\
\hline
\end{tabular}

Table 1: UK/EU ICZM policy deliberations UK/EU ICZM policy deliberations [1].

- Mansands in Devon; Cayton Bay in Yorkshire, East Head, West Sussex, a specific example typifying local coastal intervention [10].

- Planning strategies for long areas of coastline such as the Durham Heritage Coast, where an ICZM plan seeks to regenerate the local coastal communities by recognising their historic and industrial heritage; East Riding Coastal Zone, Yorkshire; Sefton ICZM [11,12].

- $\quad$ Raising public awareness and understanding of coastal and climate change and helping communities adapt such as the Jurassic Coast Pathfinder Project and Black Ven in Dorset [10].

A 2008 report on spatial planning and ICZM in the north west of Europe called for a much closer integration between coastal management and land use planning [12].

The following case study is an example of how radical coastal intervention and changes in coastal management can be successfully integrated within the planning strategy of its hinterland.

\section{The manhood peninsula}

The Manhood Peninsula is a small, triangular peninsula of about $15 \times 20 \mathrm{~km}$ situated on the south coast of England, between Portsmouth and Bognor Regis. Forming part of the Chichester coastal plain, the peninsula is bordered by the sea on its southern side; Chichester Harbour on its western side; and Pagham Harbour on its east; and the A27 highway, the railway, Chichester and the South Downs national park to the north. There are 16 villages and settlements on the Manhood, with populations varying from 165 in Appledram to more than 10,000 in Selsey. The total population is in excess of 25,000, similar in size to Chichester, its nearest city. Employment is mainly in tourism, agriculture and horticulture, the marine industry and service sector (Figure 1).

The peninsula is under threat of flooding from the sea, rising water tables and inland waterways, mainly non-flowing ditches. It also shares many planning problems with the Netherlands and other areas in south-east England: rapid housing development; increasing conflict between housing, industry, farming and the environment and poor infrastructure.

This flat, low-lying peninsula, which projects into the Solent with Selsey at its tip, used to be one the fastest-eroding stretches of coastline in Britain until a huge investment in coast defence works, including groynes, was undertaken during the 1950s. By 1997, when the two local residents began to express their concerns, it was obvious that much of sea defences were past their day, particularly along the rural stretch of coastline between Selsey and Bracklesham, where the shingle bank protecting the hinterland was patched up every winter by resident JCBs. 


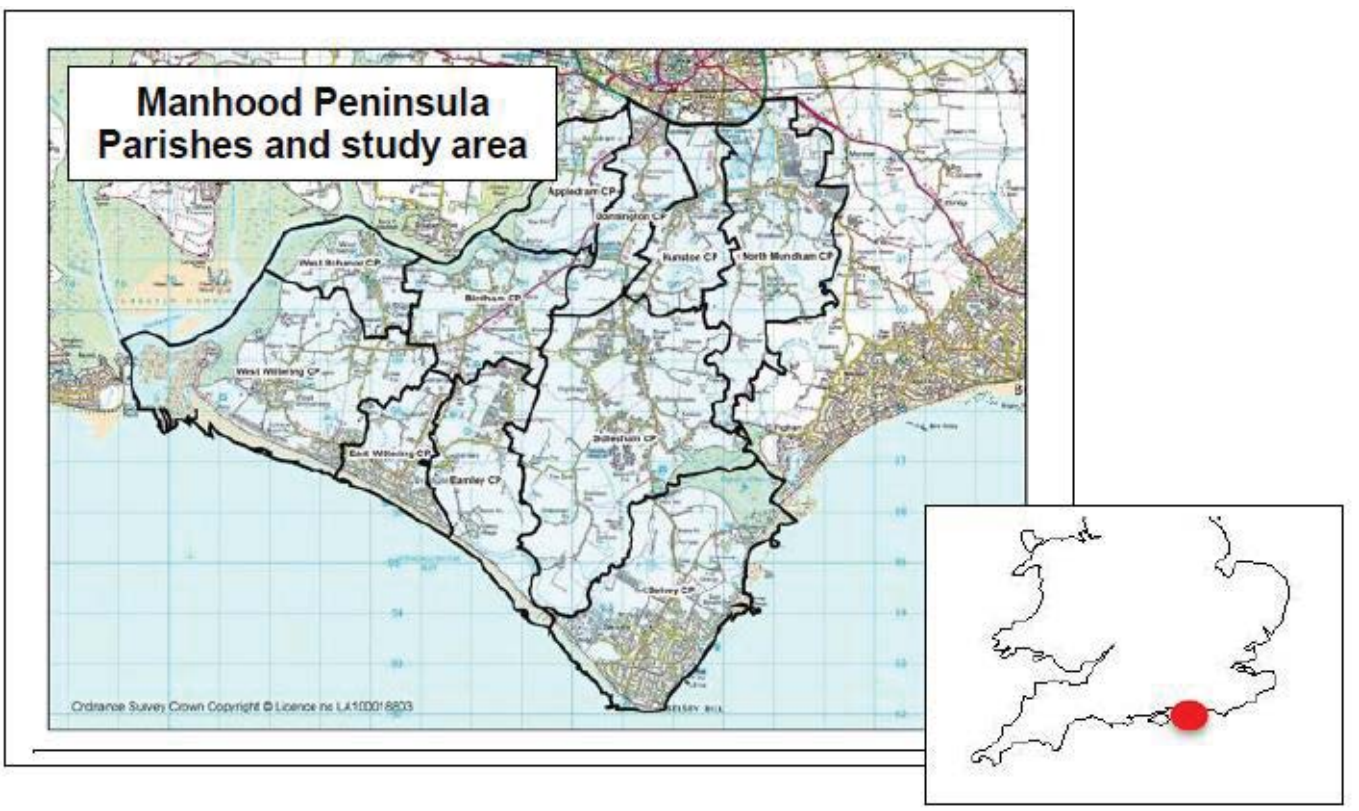

Figure 1: Map showing Manhood Peninsula parishes in the ICZM study area, and the location of the Manhood Peninsula on the south coast of England.

\section{Going dutch}

Renee Santema, a Dutch spatial planner living on the Manhood Peninsula while her husband, a Dutch flower grower, was working for a local horticultural business was surprised that planning for housing and water management were not intrinsically linked in Britain as they were in the Netherlands. Carolyn Cobbold, et al. a risk management journalist who had written about climate change since 1986, was also surprised about the extent of new house building planned for low-lying land immediately behind the small shingle bank protecting the peninsula. At the time of the planned development, no long-term coastal defence strategy for the peninsula was in place, much of the land behind the bank lay in a flood plain and the Association of British Insurers was threatening to reduce its flood risk provision to vulnerable properties.

After several years of persuading local people and businesses as well as a dozen parish councils, the district and county councils and the Environment Agency, to work more closely together, the two residents raised $£ 10,000$ to bring over two dozen leading Dutch planners, water and coastal engineers and ecologists to the Manhood for a week in March 2001 to study this vulnerable stretch of British coastline and hinterland.

The workshop participants, after surveying the area and with extensive briefing from local people and authorities, developed several scenarios for the long-term future of the area.

\section{Workshop recommendations}

Going Dutch emphasised the need for a new approach to coastal management, but pointed out that the complexity and number of parties involved in UK planning legislation made this process protracted and difficult.

According to the workshop report 'a new long term integrated approach is needed for both planning and coastal management in the UK, which takes into account the effects of climate change. This approach should link together land use planning, coastal management, water management, housing development, infrastructure, transport, economic, employment and social issues, and should be based on a long term vision' [2].

Contrary to local people's expectations the outside experts advocated a future vision of the peninsula that included the partial demolision of the shingle bank that had held back the sea for centuries and letting sea water in after building new banks further inland. Creating soft sea defences through a realignment of the coastline would provide a longer-term more sustainable approach to managing sea level rises and coastal erosion, the Dutch claimed. Moreover, the new coastal habitat that would be created would add to the considerable environmental interconnectivity and attraction of the peninsula, which already was bordered by two significant European habitat sites, Chichester and Pagham harbours. By creating a third important nature reserve the Manhood would be able to further boost its vital environmental tourism product and therefore help to regenerate its local economy, an important consideration for a beach based tourist area with eroding beaches.

The Dutch also advised that no more permanent homes should be built close to the coastline or below the 5 metre contour line [2]; that a partnership be formed of all the stakeholders involved in the area from the local community through to national agencies [2]; and that an integrated long-term spatial management policy should be developed for the area [2].

\section{The Manhood peninsula partnership}

The Manhood Peninsula Partnership was formed in 2001, following the guidelines recommended by Going Dutch. Membership 
includes local authorities (Chichester District Council and Wet Sussex County Council); national agencies (Environment Agency and English Nature (now Natural England)); representatives of local communities; and local landowners and environmental organisations including The National Trust, Chichester Harbour Conservancy, the Royal Society for the Protection of Birds and the Manhood Wildlife and Heritage Group.

The partnership meets four times a year and has been involved with, and instrumental to many strategic planning and infrastructure projects in the peninsula during the last 14 years including:

- Drainage surveys which provided benchmark data for a peninsula-wide surface water management plan commissioned by West Sussex County Council, the area's lead flood risk authority, are now in progress.

- Several planning, climate-change and economic workshops.

- $\quad$ ESPACE, a European Union funded climate change planning project.

- A British government funded Coastal Change Pathfinder project for helping coastal communities plan for and adapt to coastal change. Pathfinder was an effort to win over the hearts and minds of communities on the peninsula, and explore new ways to deal with climate change and sea level rise. News ways to approach the problems were suggested through short films, practical projects and by taking a close look at both planning and tourism in the area through Integrated Coastal Zone Management.

- A Destination Management Plan (Clegg 2011) that provides a strategy for future economic regeneration using the environment as an asset to encourage investment and tempt visitors to spend more time here [13].

- the Medmerry coastal realignment, one of the largest coastal realignment schemes in Europe, and a major new, important natural salt-marsh habitat

- plans for the development of a network of sustainable transport routes across the peninsula, including new and existing foot, bridle and cycle paths.

- The formation of the Selsey Coastal Trust to help Selsey's community shape the long-term future of the town, one of the largest population hubs in Chichester District

- Towards ICZM, which introduces the concept of integrated coastal zone management into local planning and gives the local community a co-ordinated voice (Manhood Peninsula Partnership 2011) [14].

- The adoption of Towards ICZM into the Chichester District Local Plan 2014-2029, approved by the Government Planning Inspector in 2015 .

\section{Response from the local community}

While initially surprised by the findings in the Going Dutch workshop and its report, local people began to see their surroundings with a new understanding when, a few years after the workshop, the Environment Agency changed its hold-the-line coastal defence policy in favour of a coastal realignment between Selsey and Bracklesham. Many locals were shocked but an informed minority now believed it was a sustainable policy that could bring great benefits to the area. Locals suggested repeating the Going Dutch workshop with many of the same Dutch experts, and some new ones, returning to the
Manhood in 2008 to 'stress test' the EA's proposal and look at other possible options. Going Dutch II repeated the same message as the original Going Dutch - 'Plan your future as well as your sea defences! By looking ahead and maximising your potential, you will increase the importance of protecting your area but you will also be able to judge better what type of coastal management is preferable for your economy and your environment [15].

Throughout the process of creating Medmerry, Britain's largest open coast realignment scheme, the Environment Agency worked closely with the local community, the RSPB and MPP, to design not only a coastal flood scheme but also a new nature reserve surrounding by footpaths, cyclepaths and bridleways, linking communities and creating a new asset for the peninsula's important tourism industry. When planning permission was sought for the scheme - a scheme that would effectively turn 183 hectares of our scarce land into estuarine salt-marsh, out of bounds to humans - hundreds of local people wrote in to support it with almost no objections.

\section{Framework for ICZM on the manhood peninsula}

The key conclusions and recommendations from the Going Dutch reports and on-going consultation with the local community provided the framework for an area vision, applicable to the concept of ICZM and spatial management of the peninsula. This vision included:

- Recognising and exploiting the area's potential. The peninsula should be marketed and branded more, bringing it to the attention of a wider range of people to bring more money into the area. Qualities intrinsic to the area should be recognised and promoted including seafood, local agricultural and horticultural produce, bright light, long hours of sunshine, good climate, beaches, quality of life, clean air and flat topography with wide, open views ideal for cycling, walking, horseriding.

- $\quad$ Reducing the divide in the area by uniting the two east-west halves of the peninsula, currently divided socially, economically and geographically.

- Recognising the peninsula's location as part of a wider important geographical area comprising the South Downs National Park, heritage city of Chichester and the coast and harbours.

- Choosing appropriate coastal defences by recognising the low population density in parts of the peninsula, hence the lack of funds for hard coastal defences, and the importance of the area's rural and natural environment to its tourism economy.

- Enhancing and creating synergy between the area's main economic sectors of tourism, fishing and food and flower growing (Manhood Peninsula Partnership 2011, p28)

\section{Lessons Learnt and Conclusions}

The Going Dutch project, which led to the Manhood Peninsula Partnership, and combined coastal and inland planning strategies was an initiative started well before ICZM policies began to be discussed widely in the UK. This example demonstrates how, with a groundup, co-ordinated and concerted effort comprehensive, strategic and integrated planning of the coast and hinterland can be achieved.

\section{Lessons learnt}

- Local residents can bring about huge change to their environment.

- Climate change mitigation can benefit an area 
Citation: Cunningham J, Cobbold C (2015) How Anglo/Dutch Collaboration Produced Radical Long-Term Integrated Coastal Planning Solutions for a Vulnerable Peninsula on Britain's South Coast. J Coast Zone Manag 18: S1-001. doi: 10.4172/2473-3350.1000S1-001

Page 5 of 5

environmentally, socially and economically as well as creating greater security.

- Encouraging people from different disciplines and backgrounds to brainstorm together, outside of existing political, disciplinary and administrative constraints, can produce new and interesting solutions.

- An integrated approach helps to identify short and long-term decisions, to identify problems and solutions on different levels, to identify what should be solved within the collective domain and what should be left to local and private initiatives, and also how one solution can address more than one problem and therefore create financial benefits.

- Bringing together all parties, professional, administrative, landowners, residents and businesses, from the beginning of any planning strategy increases the chance of reaching consensus.

- A vision for the area is vital to ensure long-term gains are achieved as well as short term wins and to create opportunities from problems.

Since the Going Dutch workshops in 2001 and 2008 there has been a huge increase in the value attached to the UK coast. This improvement is reflected in new legislation such as the Marine \& Coastal Access Act 2009 [16] and the Local Plans that are being produced by local planning authorities in the UK. The Local Plan for Chichester District (Chichester District Council 2015) [6] contains a number of key polies applicable to the Manhood Peninsula, in particular Policy 22 Integrated Coastal Zone Management for the Manhood Peninsula. However reductions in government and local council spending mean that although coastal regeneration schemes are supported by local communities, there is often insufficient funding to ensure they are implemented.

Projects such as Coastal Change Pathfinder and the recent Coastal Communities Fund are extremely positive national government responses to the lack of continuous funding. A new DCLG (Department of Communities \& Local Government) funded project has awarded the Manhood Peninsula Partnership money to set up a new coastal team looking at ways to regenerate the local coastal economy - the Peninsula Coastal Economy Team.

The positive view is that the new funding, however limited, provides an opportunity to 'seed fund' projects and create match funding to attract an even greater financial reward. The drawback of limited term funding schemes is that they often stop when the funding ends, leading to a lack of continuity.

Funding remains an issue, but partnerships such as the Manhood Peninsula Partnership continue their role of lobbying on coastal issues, while working to attract the elusive funding that acts as such a catalyst for change.

\section{References}

1. Collins S (2014) Integrated Coastal Zone Management. DEFRA, UK Government.

2. Cobbold C, Santema R (2001) Going Dutch on the Manhood Peninsula Unpublished report to NIROV Werkgroep Landscap.

3. Department for Environment, Food \& Rural Affairs - Defra (2009) A strategy for promoting an integrated

4. approach to the management of coastal areas in England.

5. Department for Communities \& Local Government - DCLG (2012) National Planning Policy Framework.

6. Chichester District Council (2009) Sustainable Community Strategy 2009-2016 Chichester District: A Very Special Place.

7. Chichester District Council (2015) Chichester Local Plan 2014-2029.

8. Marine Management Organisation.

9. Cummins V, Mahony OC, Connolly N (2004) Review of Integrated Coasta Zone Management \& Principles of Best Practice, Coastal \& Marine Resources Centre, Cork, Ireland.

10. Coastal Partnerships Network: 2015.

11. LiCCo (2013) Compendium of best practice for managing coastal change Produced by the Littoraux et Changements Cotiers project (Living with a Changing Coast or LiCCo)

12. Worsley AT, Lynbery G, Booth CA, Wisse P, Holden VJC (2015) The Sefton Coast Partnership. An Overview of its Integrated Coastal Zone Management.

13. Ballinger R (2008) Spatial Planning and ICZM in North West Europe. COREPOINT.

14. Clegg A (2011) Manhood Peninsula Destination Management Plan 2011 - 2016 Unpublished report by the University of Chichester to the Manhood Peninsula Partnership and Visit Chichester.

15. Manhood Peninsula Partnership (2011) Towards ICZM on the Manhood Peninsula. Unpublished report to Defra Coastal Change Pathfinder Project and Chichester District Council.

16. Cobbold C, Santema R (2008) Going Dutch II. Unpublished report for NIROV Werkgroep Landscap.

17. Marine \& Coastal Access Act (2009) Act of Parliament for the United Kingdom.
This article was originally published in a special issue, entitled: "Integrated Coastal Zone Management", Edited by Javier Garcia Sanabria, University of Cadiz, Spain 